\title{
Arachnidism, scorpionism and ophidism in Ouro Preto Municipality, Minas Gerais State, Brazil
}

\author{
Gabriela Fernanda Evangelista ${ }^{[1]}$ and Cristiano Schetini de Azevedo ${ }^{[1]}$
}

\begin{abstract}
[1]. Departamento de Biodiversidade, Evolução e Meio Ambiente, Instituto de Ciências Exatas e Biológicas,
\end{abstract} Universidade Federal de Ouro Preto, Ouro Preto, Minas Gerais, Brasil.

\begin{abstract}
Introduction: This retrospective study shows the profile of arachnidism, ophidism, and scorpionism in the Ouro Preto Municipality, Brazil, from January 2007 to December 2013. Methods: The data were gathered from forms of the Epidemiological Surveillance Sector of the town's Health's Municipal Secretary. Results: Of the 412 envenomations, 308 were caused by spiders, 78 by scorpions, and 26 by snakes. The highest number of incidents involved people aged 20-34 years. Females were more affected than males. There were no reports of death. Conclusions: The results show that envenomations caused by spiders, scorpions and snakes have decreased in recent years.
\end{abstract}

Keywords: Arachnidism. Scorpionism. Ophidism.

Injuries caused by venomous animals constitute a public health problem in Brazil. Between 2010 and 2013, the number of incidents involving venomous animals grew continuously $(106,135$ notifications in $2010,116,033$ in $2011,116,641$ in 2012 , and 123,128 in 2013)(1) (2). The number of incidents caused by venomous animals continued to increase in Brazil until 2013, but the number of deaths caused by this type of incident remained almost the same between 2010-2013 (mean of 236 deaths) $)^{(1)(2)}$.

Considering that retrospective studies about arachnidism, scorpionism, and ophidism in the Municipality of Ouro Preto are nonexistent and that this kind of study is indispensable for the delineation of strategies for preventing incidents involving venomous animals, the present study aims to report the occurrence of such incidents during the period from 2007 to 2013, relating incident occurrence with epidemiological data, such as gender, age group, bite site, deaths, and type of envenomation.

The study was conducted in the Ouro Preto Municipality (S $20^{\circ} 23^{\prime}, \mathrm{W} 43^{\circ} 30^{\prime}$ ), located in Minas Gerais State, Southeastern Brazil. Data about arachnidism, scorpionism, and ophidism in the Ouro Preto were gathered from the analysis of medical reports stored by the Epidemiological Surveillance Sector of the Municipal Health Secretary, between the years of 2007 and 2013. The information related to the injured patient (gender and age group) and to the incident (anatomic site, death, year,

Corresponding author: Dr. Cristiano Schetini de Azevedo.

e-mail: cristianoroxette@yahoo.com

Received 15 February 2016

Accepted 8 September 2016 and type of incident) was extracted from these medical reports. Spiders, scorpions, and snakes, whenever collected by the victims, were identified by zoologists of the Universidade Federal de Ouro Preto (snakes: Maria Rita Silvério Pires) and by the staff of Fundação Ezequiel Dias (spiders and scorpions: Gilson Farias; snakes: Flávia Cappuccio de Resende). If the specimen was not collected by the victim, the staff of the Epidemiological Surveillance Sector of the Municipal Health Secretary of Ouro Preto identified the animal responsible for the envenomation based on the victim's report and injury characteristics.

During the period evaluated, there were no deaths recorded for any of the types of incident (spider, scorpion or snake). The distribution and the frequency of each incident, per year, are shown in Table 1. A total of 412 incidents involving spiders, scorpions, and snakes occurred in the Ouro Preto Municipality between 2007 and 2013. The total number of incidents diminished through decade, increasing slightly in 2012 and 2013 (Table 1).

Incidents were more frequent in people aged 15-19 (46; $11.2 \%), 20-34(133 ; 32.3 \%)$ and $35-49$ years $(75 ; 18.2 \%)$. The lowest number of incidents occurred in those $\geq 80$ years old $(4 ; 0.9 \%)$; there were no incident reports involving children under one year old. With the exception of the years 2009, 2010, 2011 , and 2012, women were bitten more frequently than men (207; 50.3\% women; $205 ; 49.7 \%$ men, in total).

The number of incidents in urban areas was higher than the number of incidents in rural and peri-urban areas (324 incidents in urban areas, 79 in peri-urban areas, and 4 in rural areas). Legs $(84 ; 20.4 \%)$ and feet $(91 ; 22.1 \%)$ were bitten more frequently than other body parts. The head was the least frequently bitten body part of the victims $(2 ; 0.5 \%)$. 
TABLE 1

Annual distribution of the incidents provoked by spiders, scorpions, and snakes in the Ouro Preto Municipality between the years of 2007 and 2013.

\begin{tabular}{|c|c|c|c|c|c|c|c|c|}
\hline Year & \multicolumn{2}{|c|}{ Total } & \multicolumn{2}{|c|}{ Spider } & \multicolumn{2}{|c|}{ Scorpion } & \multicolumn{2}{|c|}{ Snake } \\
\hline 2007 & 161 & 39,1 & 137 & 44,5 & 19 & 24,4 & 5 & 19,3 \\
\hline 2008 & 104 & 25,2 & 98 & 31,8 & 0 & 0 & 6 & 23,1 \\
\hline 2009 & 38 & 9,2 & 18 & 5,8 & 9 & 11,5 & 11 & 42,3 \\
\hline 2012 & 29 & 7,0 & 16 & 5,2 & 12 & 15,4 & 1 & 3,8 \\
\hline 2013 & 32 & 7,8 & 16 & 5,2 & 15 & 19,2 & 1 & 3,8 \\
\hline Total & 412 & 100.0 & 308 & 100.0 & 78 & 100.0 & 26 & 100.0 \\
\hline
\end{tabular}

When evaluating only cases of arachnidism, the number of incidents involving brown-spiders (Loxosceles) was higher than the number of incidents involving wandering spiders (Phoneutria), black-widows (Latrodectus), and other spider species (wolf spiders of the genus $L y \cos a$ ) (Table 2). Of the 308 cases, 245 were provoked by spiders of the genus Loxosceles. In the 78 cases of scorpionism, a yellow scorpion (Tityus serrulatus) caused the only envenomation where the animal was identified; in all other cases, the scorpion species was ignored.

The frequency of snake incidents in each year evaluated is shown in Table 3. Bothropic incidents occurred more frequently than incidents with other snake species, and no incident involving a non-venomous snake was reported. However, in most records the snake identification was missing (Table 3).

Over seven years, the number of envenomations by venomous animals recorded in Ouro Preto municipality decreased, but not entirely (exhibited a slight increase in the last two years evaluated). The zoonosis staff conducted training courses for the prevention and control of envenomation by venomous animals, which, in fact, has contributed to a decrease in the number of occurrences of this type of injury in the municipality over time.

Being a historical town with very old buildings, Ouro Preto presents characteristics that facilitate a higher frequency of envenomation by spiders and scorpions. These animals adapt well to modified urban environments and find in them more stable environmental conditions, with an abundance of prey and a scarcity of predators, which facilitates their proliferation and the installation of large populations ${ }^{(3)}$.

There were 26 envenomations by snakes, 19 cases recorded in the countryside, indicating, in this case, that envenomations caused by snakes are less common in the urban area of Ouro Preto. Snakes are also easily found in urban areas, however, due to the fact that they are the most feared animals, larger, and more easily spotted by people when encountered than spiders and scorpions, snakes are quickly killed ${ }^{(4)}$, turning envenomations into rare events.

Most of the incidents were concentrated in the 20-34-yearold age group. This group contains the most active people, with workers of various employment sectors. People in these

TABLE 2

Annual distribution and frequency of the types of incident provoked by spiders in Ouro Preto Municipality between the years of 2007 and 2013.

\begin{tabular}{|c|c|c|c|c|c|c|c|c|c|}
\hline Type of incident & \multicolumn{7}{|c|}{ Year } & \multicolumn{2}{|c|}{ Total } \\
\hline Phoneutrism & 0 & 2 & 4 & 1 & 2 & 0 & 1 & 10 & 3,2 \\
\hline Loxoscelism & 131 & 95 & 10 & 5 & 1 & 1 & 2 & 245 & 79,5 \\
\hline Latrodectism & 0 & 0 & 1 & 0 & 0 & 0 & 0 & 1 & 0,3 \\
\hline Unknown & 6 & 0 & 0 & 4 & 3 & 9 & 9 & 31 & 10,1 \\
\hline Total & 137 & 98 & 18 & 16 & 7 & 16 & 16 & 308 & 100.0 \\
\hline
\end{tabular}


TABLE 3

Annual distribution and frequency of the types of incident provoked by snakes in Ouro Preto Municipality between the years of 2007 and 2013.

\begin{tabular}{|c|c|c|c|c|c|c|c|c|c|}
\hline Type of incident & \multicolumn{7}{|c|}{ Year } & \multicolumn{2}{|c|}{ Total } \\
\hline Bothropic & 4 & 6 & 8 & 2 & 0 & 0 & 0 & 20 & 77,0 \\
\hline Crotalic & 0 & 0 & 1 & 0 & 0 & 0 & 1 & 2 & 7,7 \\
\hline Elapidic & 0 & 0 & 0 & 0 & 0 & 0 & 0 & 0 & 0.0 \\
\hline Non-venomous & 0 & 0 & 1 & 0 & 0 & 0 & 0 & 1 & 3,8 \\
\hline Unknown & 1 & 0 & 1 & 0 & 0 & 1 & 0 & 3 & 11,5 \\
\hline Total & 5 & 6 & 11 & 2 & 0 & 1 & 1 & 26 & 100.0 \\
\hline
\end{tabular}

age groups are more vulnerable to venomous animals due to their greater chance of encountering these animals during their daily activities ${ }^{(2)}(5)$.

No gender effect was observed in this study, with males and females at equal risk of suffering an envenomation by venomous animals in Ouro Preto. This result could be due to characteristics of the study area: women in Ouro Preto tend to stay at home more than men $^{(6)}$. The majority of the buildings in the city are old, having cracks, rubble, and other places that serve as shelter for the animals. Besides, Ouro Preto is a cold town, and there is a tendency for people to keep warm with coats, socks, and shoes, objects utilized as hiding places by spiders and scorpions ${ }^{(7)}$.

Legs and feet were stung more frequently than any other body part. This was also observed in other studies ${ }^{(5)(8)}$ and could be explained by the greater probability of legs and feet to be in contact with the venomous animals, especially when they hide inside clothes.

Taking into account only the reports of arachnidism, envenomations caused by the brown-spider Loxosceles were the most common in Ouro Preto. This is considered the most serious and more important form of arachnidism in South America; it normally occurs in the southern and southeastern states of Brazil $^{(9)}$. Studies showed that the spider bite usually occurs in the domestic environment, in situations in which the spider is compressed against the individual's body ${ }^{(10)(11)}$. The species of the genus Loxosceles have generalist habits and are more active, moving more frequently through the area, which facilitates the colonization of different environments and substrates, favoring the expansion of the occurrence area of the $\operatorname{species}^{(12)}$. L. similis and L. gaucho are common in Minas Gerais ${ }^{(13)}$ and are candidates for the brown spider species of Ouro Preto.

Envenomations involving snakes of the genus Bothrops were the most common in Ouro Preto $(77 \%)$, while in Brazil it was $90 \%{ }^{(14)}$. These snakes live in peri-urban areas and are known to be aggressive when disturbed, facilitating the occurrence of incidents.

The results of this study can help health authorities of Ouro Preto Municipality to plan more effective actions to combat and prevent envenomation by venomous animals in the coming years.

\section{Ethical considerations}

This study was approved by the Committee of Ethics of the Federal University of Ouro Preto (process n ${ }^{\circ} 502.811$ ).

\section{Acknowledgements}

The authors thank the Epidemiological Surveillance Sector of the city's Municipal Health Department for providing information that helped in the realization of this study.

\section{Conflict of interest}

The authors declare that there is no conflict of interest.

\section{Financial Support}

There was no financial support for this study.

\section{REFERENCES}

1. Chippaux J-P. Epidemiology of envenomations by terrestrial venomous animals in Brazil based on case reporting: from obvious facts to contingencies. J Venom Anim Toxins Inc Trop Dis 2015; 21:13.

2. Silva AM, Bernarde PS, Abreu LC. Accidents with poisonous animals in Brazil by age and sex. J Hum Growth Dev 2015; 25:5462.

3. Foelix RF. Biology of Spiders. $3^{\text {rd }}$ edition. Oxford: Oxford University Press; 2010. 432p.

4. Moura MR, Costa HC, São-Pedro VA, Fernandes VD, Feio RN. O relacionamento entre pessoas e serpentes no leste de Minas Gerais, sudeste do Brasil. Biota Neotrop 2010; 10:133-141.

5. Oliveira HFA, Costa CF, Sassi R. Injuries caused by venomous animals and folk medicine in farmers from Cuité, State of Paraíba, Northeast of Brasil. Rev Bras Epidemiol 2013; 16:633-643.

6. Instituto Brasileiro de Geografia e Estatística (IBGE). Census 2010: Results of the Universe - Characteristics of the Population and Households, Ouro Preto City, Minas Gerais, 2014. Cited 2014 Jul 02. Available from: http://www.cidades.ibge.gov.br/ $\mathrm{xtras} /$ temas.php?lang $=\& \operatorname{codmun}=314610 \&$ idtema $=67 \&$ search $=\mathrm{m}$ inas-gerais|ouro-preto|censo-demografico-2010:-resultados-douniverso-caracteristicas-da-populacao-e-dos-domicilios-. 
7. Ramalho MG. Acidentes com animais peçonhentos e assistência em saúde. Trabalho de Conclusão do Curso de Enfermergem. Brasília: Centro Universitário de Brasília; 2014. 27p.

8. Bredt CS, Litchteneker K. Avaliação clínica e epidemiológica dos acidentes com animais peçonhentos atendidos no Hospital Universitário do Oeste do Paraná 2008-2012. Rev Med Res 2014; 16:11-17.

9. Malaque CMS, Chaim OM, Entres M, Barbaro KC. Loxosceles and Loxoscelism: biology, venom, envenomation and treatment. In: Corzo G, Lima ME, Diego-Garcia E, editors. Spider Venoms. Netherlands: Springer; 2014. p. 1-22.

10. Isbister GK, Gray MR. White-tail spider bite: a prospective study of 130 definite bites by Lampona species. Med J Aust 2003; 179:199-202.

11. Málaque CM, Castro-Valencia JE, Cardoso JLC, França FOS, Barbado KC, Fan HW. Clinical and epidemiological features of definitive and presumed loxoscelism in São Paulo, Brazil. Rev Inst Med Trop São Paulo 2002; 44:139-143.

12. Fischer ML. Biologia e ecologia de Loxosceles intermedia MelloLeitão, 1934 (Araneae; Sicariidae) no Município de Curitiba, PR. Dissertação de Mestrado. Curitiba: Universidade Federal do Paraná; 1996. 137p.

13. Machado EO, Álvares ESS, de Maria M, Kalapothakis E. On the presence of three species of Loxosceles Heineken \& Lowe (Araneae: Sicariidae) in the municipality of Belo Horizonte, Minas Gerais, Brazil. Lundiana 2005; 6:113-115.

14. Fundação Nacional de Saúde (FUNASA). Vigilância Epidemiológica. Manual de Diagnóstico e Tratamento de Acidentes por Animais Peçonhentos. $2^{\text {th }}$ edition. Brasília: FUNASA; 2001. p. 1-112. 


\section{Erratum}

\section{Revista da Sociedade Brasileira de Medicina Tropical/Journal of the Brazilian Society of Tropical Medicine 49(6):nov-dec, 2016 - doi: 10.1590/0037-8682-0047-2016 - Page 788-789 - References List}

\section{REFERENCES}

1. Lainson R, Shaw JJ, Ryan L, Ribeiro RSM, Silveira FT. Leishmaniasis in Brazil XXI: visceral Leishmaniasis in the Amazon region and further observations on the role of Lutzomyia longipalpis (Lutz \& Neiva, 1912) as the vector. Trans Roy Soc Trop Med Hyg 1985; 79:223-226.

2. Lainson R, Rangel EF. Lutzomyia longipalpis and the ecoepidemiology of American visceral leishmaniasis, with particular reference to Brazil - A review. Mem Inst Oswaldo Cruz 2005; 100:811-827.

3. Vilela ML, Afonso MMS, Costa SM, Costa WA, Rangel RF. Lutzomyia (Lutzomyia) longipalpis: fatores associados ao processo de expansão e urbanização da leishmaniose visceral americana. In: Conceição-Silva F, Alves CR, organizadores. Leishmanioses do Continente Americano. $1^{\text {a }}$ edição. Rio de Janeiro: FIOCRUZ; 2014. p.183-192.

4. Rotureau B. Ecology of the Leishmania species in the Guianan ecoregion complex. Am J Trop Med Hyg 2006; 74:81-96.

5. Forattini OP, Juarez E, Bernardi L, Dauer C. Leishmaniose tegumentar, no território do Amapá, Brasil. Rev Inst Med Trop São Paulo 1959; 1:11-17.

6. Forattini OP. Sobre os flebótomos do território do Amapá, Brasil. Arq Fac Hig Saude Publica Univ São Paulo 1959; 3:159-164.

7. Aguiar GM, Medeiros WM. Distribuição regional de habitats das espécies de flebotomíneos do Brasil. In: Rangel EF, Lainson R, editores. Flebotomíneos do Brasil. Rio de Janeiro: FIOCRUZ; 2003. p. 207-256.

8. Galardo AKR, Galardo CD, Santana AA, Mendes JCC, Souza FRA, Duarte JP, et al. Primeira ocorrência de Lutzomyia (Lutzomyia) longipalpis Lutz \& Neiva, 1912 (Diptera: Psychodidae: Phlebotominae) no Estado do Amapá, Brasil. Biota Amazon 2013; 3:179-183.

9. Ryan L, Lainson R, Shaw JJ, Braga RR, Ishikawa EA. Leishmaniasis in Brazil. XXV. Sandfly vectors of Leishmania in Pará State, Brazil. Med Vet Entomol 1987; 1:383-395.

10. Silva CR, Martins ACM, Castro IJ, Bernard E, Cardoso EM, Lima DS, et al. Mammals of Amapá State, Eastern Brazilian Amazonia: a revised taxonomic list with comments on species distributions. Mammalia 2013 77:409-424.

11. Thoisy B, Vergara M, Silvestro P, Vasconcelos I. Northern extensions of records the crab-eating fox in Brazil. Canid Biol Conserv 2013; 16:1-3.

12. Rotureau B, Ravel C, Aznar C, Carme B, Dedet JP. First report of Leishmania infantum in French Guiana: canine visceral leishmaniasis imported from the Old World. J Clin Microbiol 2006; 44:1120-1222.

13. Werneck G. Expansão geográfica da leishmaniose visceral no Brasil. Cad Saude Publica 2010; 26:644-645.

14. Ministério da Saúde. Secretaria de Vigilância em Saúde Departamento de Vigilância Epidemiológica. Manual de vigilância e controle da leishmaniose visceral. $1^{\text {st }}$ edição. Brasília: Ministério da Saúde; 2006.

\section{Should read:}

\section{REFERENCES}

1. Chippaux J-P. Epidemiology of envenomations by terrestrial venomous animals in Brazil based on case reporting: from obvious facts to contingencies. J Venom Anim Toxins Inc Trop Dis 2015; 21:13.

2. Silva AM, Bernarde PS, Abreu LC. Accidents with poisonous animals in Brazil by age and sex. J Hum Growth Dev 2015; 25:5462.

3. Foelix RF. Biology of Spiders. $3^{\text {rd }}$ edition. Oxford: Oxford University Press; 2010. 432p.

4. Moura MR, Costa HC, São-Pedro VA, Fernandes VD, Feio RN. O relacionamento entre pessoas e serpentes no leste de Minas Gerais, sudeste do Brasil. Biota Neotrop 2010; 10:133-141.

5. Oliveira HFA, Costa CF, Sassi R. Injuries caused by venomous animals and folk medicine in farmers from Cuité, State of Paraíba, Northeast of Brasil. Rev Bras Epidemiol 2013; 16:633-643.

6. Instituto Brasileiro de Geografia e Estatística (IBGE). Census 2010: Results of the Universe - Characteristics of the Population and Households, Ouro Preto City, Minas Gerais, 2014. Cited $2014 \mathrm{Jul}$ 02. Available from: http://www.cidades.ibge.gov.br/ $\mathrm{xtras} /$ temas.php?lang $=\& \operatorname{codmun}=314610 \&$ idtema $=67 \&$ search $=\mathrm{m}$ inas-gerais|ouro-preto|censo-demografico-2010:-resultados-douniverso-caracteristicas-da-populacao-e-dos-domicilios-.

7. Ramalho MG. Acidentes com animais peçonhentos e assistência em saúde. Trabalho de Conclusão do Curso de Enfermergem. Brasília: Centro Universitário de Brasília; 2014. 27p.
8. Bredt CS, Litchteneker K. Avaliação clínica e epidemiológica dos acidentes com animais peçonhentos atendidos no Hospital Universitário do Oeste do Paraná 2008-2012. Rev Med Res 2014; 16:11-17.

9. Malaque CMS, Chaim OM, Entres M, Barbaro KC. Loxosceles and Loxoscelism: biology, venom, envenomation and treatment. In: Corzo G, Lima ME, Diego-Garcia E, editors. Spider Venoms. Netherlands: Springer; 2014. p. 1-22.

10. Isbister GK, Gray MR. White-tail spider bite: a prospective study of 130 definite bites by Lampona species. Med J Aust 2003; 179:199-202.

11. Málaque CM, Castro-Valencia JE, Cardoso JLC, França FOS, Barbado KC, Fan HW. Clinical and epidemiological features of definitive and presumed loxoscelism in São Paulo, Brazil. Rev Inst Med Trop São Paulo 2002; 44:139-143.

12. Fischer ML. Biologia e ecologia de Loxosceles intermedia MelloLeitão, 1934 (Araneae; Sicariidae) no Município de Curitiba, PR. Dissertação de Mestrado. Curitiba: Universidade Federal do Paraná; 1996. 137p.

13. Machado EO, Álvares ESS, de Maria M, Kalapothakis E. On the presence of three species of Loxosceles Heineken \& Lowe (Araneae: Sicariidae) in the municipality of Belo Horizonte, Minas Gerais, Brazil. Lundiana 2005; 6:113-115.

14. Fundação Nacional de Saúde (FUNASA). Vigilância Epidemiológica. Manual de Diagnóstico e Tratamento de Acidentes por Animais Peçonhentos. $2^{\text {th }}$ edition. Brasília: FUNASA; 2001. p. $1-112$. 